\title{
Stem Cell Research and Therapies in Argentina: The Legal and Regulatory Approach
}

\author{
Fabiana C. de Arzuaga*
}

\section{ABSTRACT}

Argentina has a significant number of researchers in public and private institutions conducting research in regenerative medicine and stem cells. There is not specific legislation in this area; however, the National Ministry of Health has issued regulations under the scope of the Transplant Act and the Medicines Act. Alongside the groups doing research, it is possible to find professionals offering experimental stem cell therapies to patients. These professionals take refuge in the term "medical practice" and sell experimental treatment to patients with no guarantee of safety and security given that they were not tested in clinical research. These practices offered to patients in a scheme, apparently legal, are generating an important number of judicial actions requesting the payment of said treatments. The decisions of the courts ordering payment in most cases are generating a transfer of funds from patients, social welfare systems, and the state to medical centers offering stem cell experimental therapies. This article describes the current regulations as well as the course of action to solve the emerging problems of these new technologies at legislative level.

\section{INTRODUCTION}

In Argentina, there are at least 45 groups from both public and private institutions conducting research in different branches of medicine such as neurology, diabetes, hematology, and cardiology, with a significant number of them undertaking work in regenerative medicine. The institutions in which they develop this type of research have proven scientific backgrounds and support structures, the most prominent ones being the Schools of Medicine and

Ministry of Science, Technology and Productive Innovation, Advisory Commission on Cellular

Therapies and Regenerative Medicine, Buenos Aires, Argentina.

*(Correspondence: fabianaarzuaga@fibertel. com.ar)
Biological Sciences at the University of Buenos Aires, the Fleni Institute, the Italian Hospital, the Leloir Foundation, the Favaloro Foundation, and the Austral Hospital.

Most of this research is funded by the Ministry of Science, Technology and Productive Innovation (MINCYT) through different programs such as National Fund for Technology of Argentina (FONTAR) and National Fund for Science and Technology Research (FONCYT), as well as subordinate bodies such as the National Agency for the Promotion of Science and Technology. ${ }^{1}$ The MINCYT has also set

${ }^{1}$ See www.mincyt.gov.ar

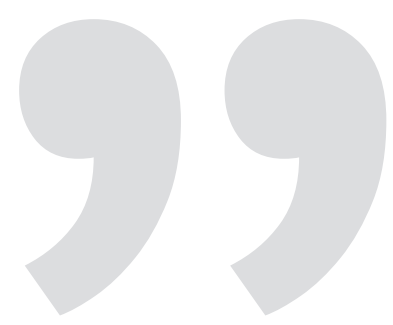

Aside from the experimental context, clinical research is not legislatively regulated in Argentina at the national level. up CICEMA, a consortium for stem cell research, and PROBITEC, an Argentine-Brazilian bi-national research program. ${ }^{2}$ Most of this domestic research focuses on basic research, though some groups are moving into clinical research, and The Unique Central Institute for Ablation and Implantation (INCUCAI), the Argentine research regulatory authority, thus far approved three research projects for phase I clinical trials (security testing and dose size). ${ }^{3}$

${ }^{2}$ See www.cicema.org.ar and www.mincyt.gob.ar/ programa/probitec-programa-binacional-deterapia-celular-6420

${ }^{3}$ See www.incucai.gov.ar 
Regulatory framework and regulatory authorities

While Argentina has not adopted legislation in the regenerative medicine research setting specifically, the national Ministry of Health has issued regulations under the scope of the Transplant Act 1993, as amended, ${ }^{4}$ and the Medicines Act 1964, as amended. ${ }^{5}$

The direct antecedent of the use of stem cells for therapeutic purposes is the hematopoietic progenitor cell (HPC) transplantation from bone marrow to treat blood diseases. This practice has been performed for more than 50 years and is considered an "established practice." HPC transplantation is regulated by the Transplant Act 1993, and its regulatory authority is INCUCAI, which has issued regulations governing certain technical and procedural aspects of this practice.

INCUCAI Resolution 307/2007 establishes the classification of medical indications for autologous, allogeneic, and unrelated transplantation of HPC. It also covers procedures for tissue banking, including the banking of stem cells from umbilical cord blood (UCB), which is an alternative source of HPC used in transplants in replacement of bone marrow. INCUCAI Resolution 069/2009 regulates the activity of UCB banks and states that all units collected as of the date of its entry into force, for which there is no established medical indication, will be registered in the National Registry of Hematopoietic Stem Cell Donors and will be available for use as established by Act 25.392. ${ }^{6}$ Thus, Resolution 069/2009 establishes the practice of "eventual own use" and, on this basis, has been challenged as unconstitutional

${ }^{4}$ Organs and Anatomic Human Material Transplantation Act, Act 24.193, of 24 March 1993, modified by Act 26.066 .

${ }^{5}$ Commercialization Regime of Medicinal Products Act, Act 16.463, of 8 August 1964, and Decree 9763/1964.

${ }^{6}$ Creation of the National Registry of Hematopoietic Stem Cell Donors Act, Act 25.392, of 10 January 2001. with the complainants (parents of babies' UCB stored in banks and owners of private UCB banks) arguing that INCUCAI acceded its authority in regulating a right while not allowing the possibility of "preserving without donating." The court of first instance accepted this argument and it was upheld on appeal. The attorney general of the nation held the same position when the case reached the Argentine Supreme Court. The decision of the Supreme Court is still pending. ${ }^{7}$

\section{Ministry of Health}

\section{regulations on the use of human cells under the Transplant Act}

Faced with the increased development and delivery at bedside of stem cell-based treatments that did not fit well into the current regulatory regime applicable to $\mathrm{HPC}$, the Ministry of Health, under the Transplant Act 1993, issued Resolution MS $610 / 2007$, which states that "activities related to the use of human cells for subsequent implantation in humans fall within the purview of the INCUCAI." This resolution formally recognizes INCUCAI's competence to deal with activities involving the implantation of cellular material into humans. The resolution is very brief and does not specify which type of cell it applies to, nor to any specific procedures (of manipulation) to which cells can be subject, an issue that is, in an event, beyond the scope of the act. Ultimately, then, it could be interpreted broadly to include embryonic stem cells, but its application to such cells is not clear from the wording.

Resolution MS 610/2007 is supplemented by Regulatory Decree 512/95, which, in Article 2, states that "any practice that involves implanting of human cells that does not fall within HPC transplantation is radically new and therefore is consid-

${ }^{7}$ Calabró, Marina Edith and others c/ Estado Nacional-INCUCAI-Resolution 69/09s/ Amparo ley 16.986. C. 526, L. XLVII Procuración General de la Nación 22/5/2012. ered as experimental practice until it is established that it is safe and effective." To start a new experimental practice, researchers or medical practitioners must seek prior authorization from the health authority (INCUCAI) and must submit a research protocol signed by the medical professional or team leader who will conduct the investigation, complying with all requirements of the regulations, including the provision of written informed consent signed by the research subject, who must not be charged to participate in the procedure.

In May 2012, INCUCAI issued Resolution 19/2012, a technical standard to establish requirements and procedures for the preparation of cellular products. Substantively, it is in harmony with international standards of good laboratory and manufacturing practices governing this matter. However, very few protocols have been filed with INCUCAI since 2007, and the delivery of unproven stem cell treatments continues to grow in Argentina.

\section{Ministry of Health}

\section{regulations on cell therapy and tissue engineering under the Medicines Act}

Another attempt by the Ministry of Health to establish a system of registration for cellular-based medicines was made through the National Administration of Drugs, Food and Medical Technology (ANMAT). ANMAT Regulation 7075/2011 defines "biological medicinal products" as "products derived from living organisms or their tissues," a definition that captures stem cell preparations, and they are categorized as Advanced Therapeutic Medicinal Products (ATMPs). ${ }^{8}$ Under this legislation, cellular-based or biological drugs must

\footnotetext{
${ }^{8}$ Requirements for the Registry of Biological Medicinal Products, ANMAT Resolution 7075/2011, of 24 October 2011. ANMAT. Disposition 7729/2011 of 21 November 2011, "Approval of requirements for the registry of biological medicinal products."
} 
be registered with the National Drugs Registry (REM), and approval for marketing, use, and application in humans falls within the scope of the Medicines Act 1964 and its implementing regulations. Cellular medicine manufacturers must register at the ANMAT as manufacturing establishments, and they must request product registration before marketing or commercializing their products.

Importantly, the above ANMAT provisions do not apply in cases where ATMPs are manufactured entirely by an authorized medical center, to be used exclusively in that center, in which case the local health authority maintains the right for approval. ${ }^{9}$ Like all regulations issued by the national Ministry of Health under the Medicines Act 1964, the provisions of Resolution 7075/2011 and Resolution $7729 / 2011$ apply only in areas of national jurisdiction or in cases where interprovincial transit is implicated or where ATMPs are imported or exported. In short, the Medicines Act 1964 is not applicable so long as the product does not leave the geographic jurisdiction of the province.

Aside from the above-mentioned experimental context, clinical research is not legislatively regulated in Argentina at the national level. ${ }^{10}$ The Ministry of Health has issued Resolution 1480/2011, which, although consistent with international standards, is restricted to public hospitals and self-management healthcare institutions, and to research and manufacturing institutions under the Ministry of Health. ${ }^{11}$ Other relevant laws

${ }^{9}$ See Article 3, ANMAT Resolution 7075/2011.

This is similar to the Hospital Exemption articulated in the Regulation (EC) No. 1394/2007 of the European Parliament and of the Council of 13 November 2007 on Advanced Therapy Medicinal Products.

${ }^{10} \mathrm{At}$ the provincial level, some regulation exists, although approaches vary between legislation, administrative rules, and no regulation at all. The provinces that have legislated are Córdoba, Buenos Aires City, Buenos Aires Province, Tucumán, Neuquén, and Rio Negro. Provinces that have issued administrative rules are Mendoza and Jujuy. ${ }^{11}$ Ministry of Health of Argentina, Resolution 1480/2011, "Good Practices for Clinical Research.” are the Professional Practice of Medicine Act $1967,{ }^{12}$ which determines the scope of medical practice but has limited scope in the provinces, and the Patient Rights Act $2009,{ }^{13}$ which regulates only matters relating to informed consent and use of patient histories. Finally, there are regulations governing clinical trials for drug testing, which are well established and clearly define the requirements for each of the four phases of clinical research, but these are not so clear in the case of cellular therapies, which are living substances (and so quite different in nature and mode of action from their chemically based counterparts). ${ }^{14}$ Although there is consensus that clinical trials of cellular therapies should comply with the same principles and criteria of other substances (including concepts such as autonomy, beneficence, justice, and nonmaleficence), it is necessary to consider additional measures given the particularities of cellular therapies and the unique risks they present; at present, the clinical trial regime allows for no such consideration.

Ultimately, one can see that, similar to many jurisdictions, Argentina's regulation of medical research has developed through multiple legal instruments and in a piecemeal fashion, an evolution that admits to gaps and under-reach. This is a state of affairs that is particularly problematic given the power of new research techniques, and their increasing contributions to novel treatments, which are, sadly, being delivered (by some) with little regard for patient safety or regulatory requirements, as noted below.

\section{Current problems}

As alluded to above, it is possible to find professionals in Argentina offering experimental stem cell therapies to patients. As in many countries, there are many ar-

\footnotetext{
${ }^{12}$ Legal Regime for Medicine, Odontology and Auxiliary Activities Act, Act 17.132, of 31 January 1967.

${ }^{13}$ Patient Rights and Its Relationships with Professional and Health Institutions Act, Act 26.529, of 20 November 2009.

${ }^{14}$ ANMAT. Disposition 6677/2010 "Good Clinical Practices for studies in clinical farmacology."
}

ticles published in the media reporting the healing — almost magical - power of stem cells, with little or no supporting evidence, and such claims have great impact on public opinion and on the decisions of individual patients. Moreover, the professionals offering these "treatments" take refuge in the independence of medical practice and the autonomy that it offers, but it seems clear that some of the practices reported are directly contrary to established professional ethics, and they threaten the safety of patients receiving the treatments..$^{15}$ In addition to the safety issues, given that these are experimental therapies (that have not been proven to be safe and effective), health insurers have stated their refusal to cover them (and one can anticipate the same antipathy to indemnifying patients who choose to accept them and are injured by them). Indeed, patients have already filed actions demanding payment of such treatments by both health insurance institutions and the national and provincial state (as guarantors of public health). ${ }^{16}$

The current regulatory regime-by virtue of its silence, its imperfect application to regenerative medicine and

\footnotetext{
${ }^{15}$ Harmon S and F Arzuaga, Project Governing Emerging Technologies: "Social Values in Stem Cell Regulation in Argentina," Award No. RES-000-22-2678. www.law.ed.ac.uk/ahrc/ esrcvaluesproject

${ }^{16}$ The following are examples of judicial cases that were reported by the lawyer of OSDE (Social Security for Company Managers), Franciso Clusellas, answering to our request of 17/07/2012:

- “Jasminoy, María Cristina c/ Osde Binario s/ Sumarísimo" (Expte. 4008/03), Court of First Instance in Civil and Commercial Matters No. 11, Secretariat No. 22. The treatment was covered by OSDE. Diagnosis: Multiple Sclerosis.

- "Silenzi de Stagni de Orfila Estela c/ Osde Binario S. A s/ Amparo" (Expte. 4475/05), National Civil Court No. 11. The treatment was covered by OSDE. Diagnosis: Multiple Sclerosis.

- "Ferrreira Mariana c/Osde Binario y otro s/Sumarísimo" (Expte. 8342/06), Civil and Commercial Federal Court No. 9, Secretariat No. 17. The court decision ordered the coverage of the treatment but it could not be implemented because the plaintiff died. Diagnosis: Leukemia.
} 
concomitant practices, and its shared authority between national and provincial bodies-permits practices to continue, and decisions of some courts have mandated the transfer of funds from the state (i.e., the social welfare system) to the medical centers offering these experimental cellular therapies. ${ }^{17}$ In short, the existing regime establishes a poorly harmonized/coordinated regulatory patchwork that has proven to be insufficient to uniformly regulate regenerative medicine (and stem cell) research and its subsequent translation into clinical practice and treatments. Moreover, attempts by regulatory authorities to stop these practices, though valiant, have proven ineffective.

As should be clear from the above, a key problem relating to the therapeutic use of stem cells is "biosecurity," and one of the main issues is the absence of any ability to control the differentiation of these stem cells in the host organism. This inability reflects a lack of knowledge that exists worldwide, and it requires further research to understand the mechanisms that regulate the process and the development of new techniques for controlling them.

\section{CONCLUSIONS AND PROPOSED SOLUTIONS}

Argentina is a federal country, and the existing legal regime is insufficient to regulate the entire spectrum of anticipatable possibilities stemming from regenerative medicine research and cellular

${ }^{17}$ OSDE has paid more than $\$ 5,000,000$ in professional fees for unproven cell therapies to comply with courts decisions. Information provided by Francisco Clucellas, lawyer in charge of the Legal Department of OSDE. Communication maintained on $07 / 20 / 2013$.

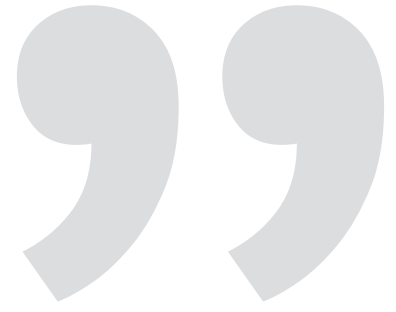

A key problem relating to the therapeutic use of stem cells is "biosecurity," and one of the main issues is the absence of any ability to control the differentiation of these stem cells in the host organism.

therapies, especially the offer of treatments not approved by health authorities, a practice that threatens the fundamental rights of patients' physical, mental, and spiritual integrity, to be informed, to make decisions freely and independently, to have sensitive personal data protected, and to enjoy the benefits of scientific progress.

The risk to these rights justifies the enactment of a law aimed specifically at cellular research in humans that is applicable throughout the country and harmonized with international standards of research and clinical conduct. By way of support for national/federal action, the Argentine constitution states that personal rights are the subject of the Civil Code and that the National Congress must pass legislation with federal enforcement (in all the provinces of the country) to ensure their enjoyment. The dictation of national rules governing biomedical research and regenerative medicine is justified as a means of protecting the fundamental rights of research subjects and patients who are exposed to risks to their life and personal rights by these practices.

Bearing this in mind, the Advisory Commission on Regenerative Medicine and Cellular Therapies (Advisory Commission), an advisory body to the MINCYT, has prepared a bill based on the idea that cellular therapies, while having similarities with conventional transplantation and drugs, have distinctive elements that give them a distinctive identity, and that this requires special provisions applicable to the clinical stages of development. For these reasons, the Working Group of the Advisory Commission tasked with developing the bill believes that both the research and clinical stages must have a specific legal definition and regulation. The bill, called "Research and Therapies with Cells," establishes a legal framework governing both cellular research and clinical translation and is applicable throughout all of Argentina. Importantly, it also contains monitoring and enforcement mechanisms that will better ensure that its values and standards are complied with. Finally, it allows for the adoption of regulations in response to scientific advances, thereby ensuring that it keeps pace with the evolution of knowledge and practices and thereby remains fit for purpose over a longer period. The bill will be sent to the National Congress before the end of 2013.

\section{Author disclosure} statement

No competing financial interests exist. 
